\title{
Promocja edycji najstarszych ksiag grodzkich krakowskich w Polskiej Akademii Umiejętności
}

\author{
Abstract \\ A Presentation of the Edition of the Oldest Castle Court Records of Cracow \\ in the Polish Academy of Arts and Sciences
}

The text in question is a report on the presentation of the edition of the oldest castle court books of Cracow from the early 15 th century. The volume was issued by three scholarly institutes, and the presentation took place in the Polish Academy of Arts and Sciences in Cracow on December 10, 2019.

Keywords: scholarly chronicle, court books, Middle Ages, Cracow, Polish terrestrial law

Słowa kluczowe: kronika naukowa, księgi sądowe, średniowiecze, Kraków, polskie prawo ziemskie

10 grudnia 2019 r. w siedzibie Polskiej Akademii Umiejętności w Krakowie odbyło się spotkanie promujące edycję najstarszych ksiąg grodzkich krakowskich ${ }^{1}$. Przyciągnęło ono kilkadziesiąt osób, wśród nich m.in. dyrektora Archiwum Narodowego w Krakowie prof. Wojciecha Krawczuka, dyrektora Archiwum Uniwersytetu Jagiellońskiego prof. Krzysztofa Ożoga, wiceprezesa Towarzystwa Miłośników Historii i Zabytków Krakowa prof. Zdzisława Nogę oraz b. kierownika Katedry Historii Prawa Polskiego UJ, prof. Wacława Uruszczaka. Spotkanie zagaił dr Waldemar Bukowski, podkreślając współudział trzech instytucji - Instytutu Historii im. Tadeusza Manteuffla PAN, Polskiej Akademii Umiejętności i Archiwum Narodowego w Krakowie - w powstaniu odnośnej edycji. Następnie głos przejął wiceprezes PAU, prof. Andrzej Mączyński, który przywitał zebranych w imieniu swoim i Prezesa Akademii, po czym krótko zarysował dzieje prac nad edycją źródeł dawnego prawa polskiego prowadzonych w Krakowie

${ }^{1}$ Najdawniejsze księgi grodzkie krakowskie z lat 1406-1409, wyd. W. Filipczyk przy współpracy M. Zdanka, wstęp W. Filipczyk i F. Sikora, Warszawa-Kraków 2019 [Starodawne Prawa Polskiego Pomniki, seria II: Pomniki Prawa Polskiego, dział I: Prawo Ziemskie, t. IV]. 
od XIX wieku, podkreślając ich ciągłość pomimo burzliwych nieraz przemian kontekstu, w którym przyszło wydawcom źródeł pracować. Po prof. Mączyńskim przemówił prof. Wojciech Krawczuk, dyrektor Archiwum Narodowego w Krakowie, podkreślając znaczenie edycji źródłowych jako tego typu prac naukowych, które wolno się starzeją, oraz wyraził nadzieję, że zadzierzgnięta przy okazji edycji najstarszych castrensiów krakowskich współpraca trzech instytucji trwać będzie także w przyszłości. Wątek ten podjęła kolejna z mówców, Katarzyna A. Chmielewska (kierownik Działu Wydawniczego IH PAN ds. finansowych), chwaląc współpracę z przedstawicielami trzech instytucji oraz przekazując zebranym pozdrowienia od prof. W. Kriegseisena i M. Słonia.

Następnie głos przejął dr Bukowski, przechodząc do szerokiej prezentacji krakowskich przedsięwzięć wydawniczych ze szczególnym uwzględnieniem edycji dawnych ksiąg sądowych, od Starodawnych Prawa Polskiego Pomników począwszy, oraz stopniowej dezintegracji ogólnopolskich planów wydawniczych na rzecz przedsięwzięć partykularnych, konstatując także stopniowe wycofanie się z działalności edytorskiej prawników na rzecz historyków. Następnie dr Bukowski przedstawił aktualny stan i plany edycji najstarszych źródeł do praktyki prawa ziemskiego w ziemi krakowskiej, wspominając także o będącym w toku opracowaniu „nowego Helcla” (wyboru zapisek sądowych opartego na wypisach Franciszka Dudy) i przygotowywaniu przez prof. T. Jurka edycji trzech najstarszych ksiąg ziemskich poznańskich. Po dr. Bukowskim głos objął Wiesław Filipczyk, który krótko zarysował historię prac nad edycją najstarszych castrensiów krakowskich (w przypadku których grant NPRH, w ramach którego zostały one ogłoszone drukiem, to jedynie finalny etap działań rozpoczętych w latach 90. XX w.), a także podkreślił szczególne merytoryczne znaczenie ksiąg grodzkich oraz wspomniał o własnych pracach mających na celu edycję także ksiąg wiecowych. Dr Bukowski podkreślił, że edycja ksiąg wiecowych byłaby realizacją postulatu zgłoszonego już dawno przez Stanisława Kutrzebę, a następnie przekazał głos dr. hab. Maciejowi Zdankowi. Ten w swym wystąpieniu nie szczędził ciepłych słów o współpracy z W. Filipczykiem, a także podkreślił swoją pomocniczą rolę $\mathrm{w}$ całym projekcie oraz duże znaczenie angażowania pracowników archiwów i bibliotek jako członków zespołów naukowych dla powodzenia szeroko zakrojonych projektów wydawniczych. Wspomniał także o wsparciu, jakie otrzymał zespół wydawców ze strony filologów łacińskich i polskich, szczególnie dr. Mariusza Leńczuka, który pomagał w rozszyfrowaniu glos staropolskich. Po wystąpieniu M. Zdanka głos zabrali ponownie dr Bukowski i K. Chmielewska, prezentując trudności edytorskie, jakich nastręczyła niełatwa materia najstarszych ksiąg grodzkich, oraz wskazując na ich skuteczne przezwyciężenie dzięki współpracy zespołu wydawców i wydawnictwa.

Następnie o głos poproszony został prof. Wacław Uruszczak jako były wieloletni kierownik Katedry Historii Prawa Polskiego UJ, wydawca źródeł i uczeń prof. Adama Vetulaniego. Wskazał on w swej wypowiedzi na zmianę uwarunkowań $\mathrm{w}$ dziedzinie nauk prawnych od czasów pierwszych wybitnych wydawców, którzy działali w czasach potęgi szkoły historycznej w prawoznawstwie. Podkreślił także, że już A.Z. Helcel i jego następcy uważali słusznie, iż do poznania dawnego prawa nie wystarczy edycja aktów normatywnych, bo to źródła praktyki, szczególnie księgi sądowe, przynoszą dogłębny i konkretny wgląd w stosowanie i rozumienie prawa w danej epoce. Głos przejął następnie dr Bukowski, dziękując wszystkim za przybycie oraz szczególnie osobom za- 
angażowanym w projekt edycji najstarszych castrensiów krakowskich, zarówno samym wydawcom, jak i osobom, które udzieliły im wsparcia na różnych etapach pracy.

Warto może zaznaczyć na marginesie niniejszej notki, że głos prof. Uruszczaka w dyskusji nie był jedyną wzmianką o krakowskim środowisku historyczno-prawnym, jaka padła w trakcie spotkania. Najpierw prof. Mączyński wspomniał zasadniczy udział historyków prawa w pracach edytorskich prowadzonych w XIX i w pierwszej połowie XX w., potem dr Bukowski przywołał opinię prof. Stanisława Grodziskiego o konieczności zrozumienia potrzeb prawoznawstwa przy edycjach źródeł praktyki prawnej, a wreszcie dr hab. Zdanek wśród serii wydawniczych, w których wydawane są drukiem źródła dawnego prawa polskiego, wymienił krakowską serię „Fontes Iuris Polonici”. Nawiązując do słów wystąpienia dr. hab. Zdanka, że krakowską specjalnością jest umiejętność współpracy różnych środowisk, warto odnotować tak miłe słowa ze strony przedstawicieli nauk historycznych, świadczące o dostrzeganiu mniejszego przecież niż kiedyś, ale narastającego nadal wkładu krakowskiego środowiska historyczno-prawnego w zakresie niewdzięcznej czasem, a jakże potrzebnej pracy edytorskiej. 